International Journal of Current Advanced Research

ISSN: O: 2319-6475, ISSN: P: 2319 - 6505, Impact Factor: SJIF: 5.995

Available Online at www.journalijcar.org

Volume 6; Issue 5; May 2017; Page No. 3802-3805

DOI: http://dx.doi.org/10.24327/ijcar.2017.3805.0371

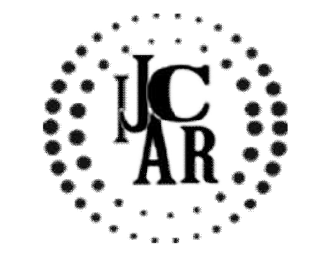

Research Article

\title{
PHYTOCHEMICAL AND ANTIOXIDANT POTENTIAL OF FRUIT AND LEAF EXTRACTS OF COCCINIA GRANDIS
}

\author{
Pavithra M.K.S., Vijayakumar L., Anjana M., Archana R., Abharna M \\ Gayatri A., Priyadharshini G., Sivaranjani E and Sumitha C
}

Department of Biotechnology, Bannari Amman Institute of Technology, India

\section{A R T I C L E I N F O}

\section{Article History:}

Received $17^{\text {th }}$ February, 2017

Received in revised form $12^{\text {th }}$ March, 2017

Accepted $8^{\text {th }}$ April, 2017

Published online $28^{\text {th }}$ May, 2017

\section{Key words:}

Bioactive, ethanolic extract, phytochemical, antioxidant, radical scavenging efficiency

\begin{abstract}
A B S T R A C T
Plants were being used in the treatment of diseases for centuries. In this present work, Coccinia.grandis, a traditionally significant plant has been studied for its potential medicinal properties. The fruits of this plant were used as the ingredient in variety of recipes all over the world. The leaves and fruits of C.grandis were collected and their ethanolic extracts were subjected to phytochemical screening and comparative analysis was done. HPLC was done to quantify the compounds present in the extracts. Antioxidant activity of the extracts was also carried out to determine the free radical scavenging efficiency of the extract. The results of the phytochemical analysis of the medicinal plant showed that the terpenoids, reducing sugar, flavonoids and proteins were found to be present in significant quantity. The comparative analysis Between the fruit and leaf extracts indicates that the fruit extract shows better antioxidant and phytochemical characteristics than the leaf extract.
\end{abstract}

Copyright $\mathrm{O} 2017$ Pavithra M.K.S et al. This is an open access article distributed under the Creative Commons Attribution License, which permits unrestricted use, distribution, and reproduction in any medium, provided the original work is properly cited.

\section{INTRODUCTION}

Coccinia grandis is a tropical plant in the family of Cucurbitaceae. It is commonly known as Ivy gourd. It is an aggressive climbing vine that can spread quickly over trees, shrubs, fences and other supporters. Being a perennial plant, it can spread vegetatively or by seed. The leaves of Coccinia grandis plant were approximately $5-10 \mathrm{~cm}$ in width and length. The leaves are bitter sweet and astringent. The Ivy gourd fruit belongs to the berry type, oval and hairless with thick and sticky skin. The raw fruit is green in colour which turns bright red on ripening. The mature fruit is usually from 25-60 mm long and $15-35 \mathrm{~mm}$ in diameter and contains several pale, flattened seeds 6-7mm long (Reddy, 2009).

The fruit possesses mast cell-stabilizing, anti-anaphylactic and antihistaminic potential. Through chemical analysis, Ivy gourd is known to be rich in $\beta$-carotene, a major precursor of vitamin A from plant sources. Besides $\beta$-carotene, it is also a good source of protein, fiber and a moderate source of calcium. The plant is used as a laxative (Pekamwaret al., 2013). Ivy gourd has been classified as one of the medicinal herbs in the traditional practice. The leaves, root, stem and fruits are used in the treatment of illness symptoms like skin eruptions, burns, insect bites, fever, indigestion, nausea and

*Corresponding author: Pavithra M.K.S

Bannari Amman Institute of Technology, India constipation to diseases such as diabetes, various types of eye infections, allergies, gonorrhoea, etc. In addition, the aqueous and methanolic extracts of the plant have shown hypoglycemic action. It helps to regulate blood sugar levels (Bamba et al., 2009).

Compounds in the plant inhibit the enzyme glucose-6phosphate which supports the body's own regulatory systems and promotes a balanced and healthy body. Therefore, it is suggested good for diabetic patients (Amir Hossain et al., 2014). Coccinia grandis contain important raw material for drug production, bioactive compounds such as secondary metabolites like alkaloids, glycoside and saponin, $\beta$-amyrine, lupeol, cucubbitacin, cephalandrol, cephalandrine, flavonoids, polysaccharides, xyloglucan, taraxerol, carotenoids, cryptoxanthin, $\beta$-sitosterol, stigma-7-en-3-one and taraxerone. It also possess antidiabetic, hypolipidemic, hepatoprotective, larvicidal, anti-inflammatory, analgesic and antipyretic activities (Tamilselvanet al., 2011). Terpenoids, saponins and flavonoids were found to be responsible for antidiabetic activity (Muniappan et al., 2009).

Cucurbitacin B is the major phytoconstituent responsible for the antioxidant activity of this plant. Antioxidants are the agents which neutralize the free radicals before they attack the cells and prevent damage to lipids, proteins, enzymes, carbohydrates and DNA (Chun 2001). A free radical is defined as any atom or molecule possessing unpaired electrons. Free radicals are highly reactive species and their overproduction may be the cause of a variety of diseases such 
as cancer, atherosclerosis, arthritis, neurodegenerative disorders, liver injury and degenerative processes associated with aging. It is also a valuable source of nutrients (Umamaheswari et al., 2009). By considering the significance of this plant, our work aimed at the quantification of leaf and fruit extracts of Coccinia grandis.

\section{MATERIALS AND METHODS}

\section{Sample collection}

The fruits and leaves of Coccinia grandis were procured from the local markets of Sathyamangalam, Tamilnadu. The raw materials were washed 2-3 times with running water and dried in shade for 15 days, grinded to fine powder separately and stored in airtight container at room temperature. $20 \mathrm{~g}$ of shade-dried fruit powder was added to a $1000 \mathrm{ml}$ roundbottomed flask and extracted with ethanol for $4 \mathrm{~h}$. The solvent extracts were concentrated under reduced pressure and preserved at $5^{\circ} \mathrm{C}$ in air tight bottle (Chandaka Madhu et al., 2013). The same process was repeated with $20 \mathrm{~g}$ of the leaf powder. The sample was then lyophilized and obtained about $4 \mathrm{~g}$ which is then prepared in the range of $50 \mathrm{mg} / \mathrm{ml}$ and used as crude sample (Aggarwal et al., 2011).

\section{Chemicals and Reagents}

Ethanol, concentrated $\mathrm{HCl}$, chloroform, concentrated $\mathrm{H}_{2} \mathrm{SO}_{4}$, $2 \% \mathrm{FeCl}_{3}, 2 \% \mathrm{NaOH}$, distilled water, Fehling solution $\mathrm{A}$ and Fehling solution B.

\section{Phytochemical screening of fruit and leaf extracts}

The fruit and leaf extracts of Coccinia grandis were screened for the presence of major bioactive constituents like proteins, carbohydrates, phenolics, flavonoids, tannins, terpenes and saponins using standard qualitative phytochemical methods as described by Trease (1989) and Harborne (1998).

\section{Determination of Total Protein Content}

The protein content of the fruit and leaf extract were determined by Lowry's method. Alkaline copper sulphate reagent was prepared using $2 \%$ sodium carbonate in $0.1 \mathrm{~N}$ $\mathrm{NaOH}, 0.5 \%$ copper sulphate and $1 \%$ sodium potassium tartrate. Folin's reagent was prepared using Folin-Ciocalteu and phenol of $1: 1$ ratio. The reaction mixture was prepared using $0.5 \mathrm{ml}$ of aqueous extract and $4.5 \mathrm{ml}$ of alkaline copper reagent. $0.5 \mathrm{ml}$ of Folin's reagent was added to the reaction mixture after 10 mins. The absorbance was determined using spectrophotometer at $660 \mathrm{~nm}$ and the protein content was estimated using a standard graph of $1 \mathrm{mg} / \mathrm{ml}$ Bovine Serum Albumin (Tamilselvan et al., 2011 and Lowry et al., 1951)

\section{Determination of Total Carbohydrates}

The crude sample was mixed with equal volume of Fehling's A and Fehling's B solution and heated in water bath. Formation of red colour indicates the presence of sugar. The absorbance was then determined using spectrophotometer at $210 \mathrm{~nm}$ for the fruit and leaf extracts (Boxi et al., 2010).

\section{Determination of Terpenoids}

Crude extract of $2 \mathrm{ml}$ was dissolved in $2 \mathrm{ml}$ of chloroform and evaporated to dryness. To this $2 \mathrm{ml}$ of concentrated $\mathrm{H}_{2} \mathrm{SO}_{4}$ was added and heated for about 2 minutes. The greyish colour indicates the presence of terpenoid. The absorbance of the fruit and leaf extracts was then estimated using spectrophotometer at $385 \mathrm{~nm}$ (Prashant et al., 2011.)

\section{Determination of Total Phenols}

The crude extract was mixed with $2 \mathrm{ml}$ of $2 \%$ solution of $\mathrm{FeCl}_{3}$. A blue green or black coloration indicates the presence of phenol. The absorbance was then measured using spectrophotometer at $760 \mathrm{~nm}$ (Martinez and Valencia, 2003).

\section{Determination of Saponins}

About $3 \mathrm{ml}$ of the extract was diluted with $2 \mathrm{ml}$ of distilled water and was shaken in a graduated cylinder for 15 minutes. Formation of $1 \mathrm{~cm}$ layer of foam indicates the presence of saponin. The quantity of saponin present in the fruit and leaf extract was measured spectrophotometrically at $430 \mathrm{~nm}$ (Sofowora, 1993).

\section{Determination of Total Sterols}

About $3 \mathrm{ml}$ of crude extract was mixed with $2 \mathrm{ml}$ of chloroform and $\mathrm{H}_{2} \mathrm{SO}_{4}$ was added. A red colour was produced in the lower chloroform layer indicating the presence of sterols. The absorbance was measured using spectrophotometer at $550 \mathrm{~nm}$ (Prashant et al., 2011).

\section{Qualitative determination of antioxidant activity}

The antioxidant activity of the leaf and fruit was determined by DPPH (2,2-diphenyl-1-picrylhydrazyl) scavenging assay. The reaction mixture was prepared by mixing $0.5 \mathrm{ml}$ of aqueous extract and $0.5 \mathrm{ml}$ of $6.5 * 10^{-3} \mathrm{M}$ DPPH in absolute ethanol. The mixture was incubated for 30 minutes. The appearance of yellow colour after incubation indicates the presence of antioxidant activity in the sample (Nanasombat and Teckchuen, 2009 and Deshpande et al., 2011).

\section{Purification and quantification}

The HPLC system (Waters, Singapore) with a photodiode array detector (W2998), dual pump system (515 waters), temperature control module II (TC2 waters), pump control module (PC2 waters), system controller (EMOAA01712), and a reverse phase HPLC analytical column waters Spherisorb $\mathrm{C} 8,4.6 \times 100 \mathrm{~mm}, 5 \mu \mathrm{m}$ particle size was used. The flow rate was adjusted to $1 \mathrm{ml} / \mathrm{min}$; the detector was set at $280 \mathrm{~nm}$ and $330 \mathrm{~nm}$ at $1.2 \mathrm{~nm}$ resolution with the mobile phase methanol: acetonitrile (80:20). The extracts were dissolved in methanol and identified by comparison of the retention time in chromatogram with standard gallic acid, rutin, quercetin,ellagic acid, and punicalagin obtained from Sigma Chemical Co, St. Louis, USA (Nanasombat et al.,2009).

\section{RESULTS AND DISCUSSION}

The phytochemical constituents present in the aqueous extract of the Coccinia grandis fruit was analysed and the results were tabulated. The presence of saponins indicates the antimicrobial, anti-inflammatory, antitussive, antihelmintic, cytotoxic property of the extract. The presence of phenols and terpenoids (Table 1) validates the anticarcinogenic activity. (Chandaka and Ramanjanyulu et al., 2013).

\section{Total Protein estimation}

The protein concentration in the leaf and fruit was determined from the standard plot of Bovine serum albumin and it was found that the concentration of the protein in the fruit was 
$29.2 \%$ more than in leaf (Table 1). (Chandaka and Ramanjaneyulu, 2013 and Gautam et al., 2014).

Table I Phytochemistry of Coccinia grandis

\begin{tabular}{cccc}
\hline \multirow{2}{*}{ S.No } & Particulars & \multicolumn{2}{c}{ Concentration $(\mathbf{m g} / \mathbf{m l})$} \\
\cline { 3 - 4 } 1. & Total Proteins & Leaf & Fruit \\
2. & Total Carbohydrates & 0.434 & 0.613 \\
3. & Total Phenolics & 0.134 & 0.2 \\
4. & Saponins & 0.763 & 0.097 \\
5. & Terpenoides & 0.680 & 1.142 \\
\hline
\end{tabular}

\section{Total Carbohydrate estimation}

The carbohydrate concentration in the leaf and fruit was determined from the standard plot of glucose and it was found that (Table 1) the concentration of the carbohydrate in the fruit was $12.5 \%$ more than in leaf (Shaheen et al., 2009 and Gautam et al., 2014).

\section{Total Phenolics estimation}

The phenolic concentration (Table I) in the leaf and fruit was determined from the standard plot of gallic acid and it was found that the concentration of the phenolics in the fruit was 29.2\% less than that in leaf. (Shaheen et al., 2009, Gautam et al., 2014).

\section{Antioxidant activity}

The antioxidant activity of the leaf and fruit extracts was qualitatively determined (Figure I) by DPPH scavenging assay. The formation of yellow colored complex with the leaf and fruit infers the presence of antioxidants in the extract. But there prevails huge difference in the development of the color in the extracts. In the leaf, it was pale yellow while in fruit it was dark yellow color. This shows that the fruits have high antioxidant activity qualitatively compared to the leaves. (Nanasombat and Teckchuen 2009, Deshpande et al., 2011)

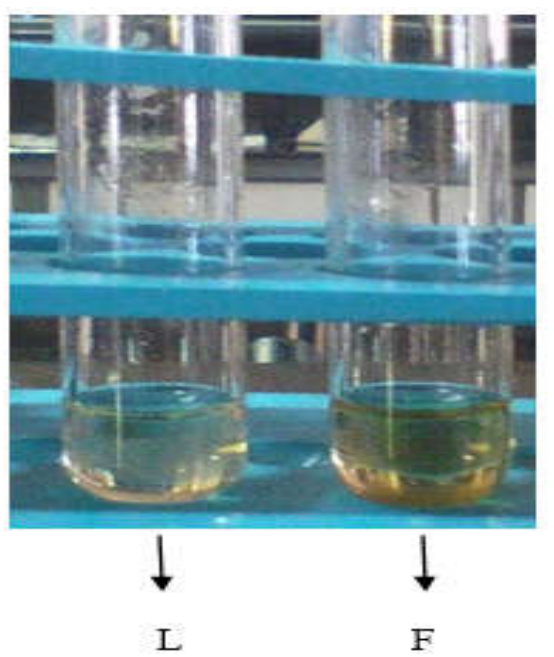

Figure I Antioxidant assay for leaf(L) and fruit(F) extract

\section{Quantification by HPLC}

The polyphenols and flavonoids present in leaf and fruit were analyzed using HPLC. The obtained results were compared with standard profile to quantify the compounds present in both the extracts. (Tamilselvan et al., 2011). As a result (Figure II, III, IV and V), it was found that the number of peaks for polyphenols is found to be more in leaf than in fruits which determines that the leaf is considered to have more compounds compared to the fruit.

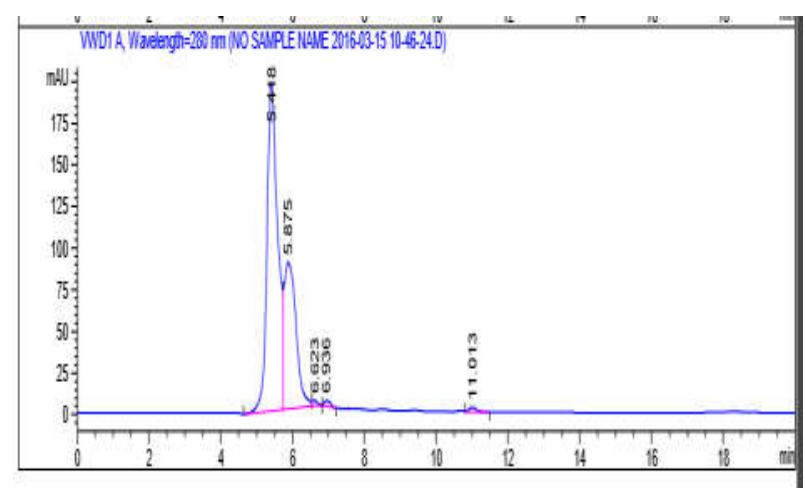

Figure II HPLC Profile of Coccinia grandis (fruit) at 280nmEstimation of polyphenols

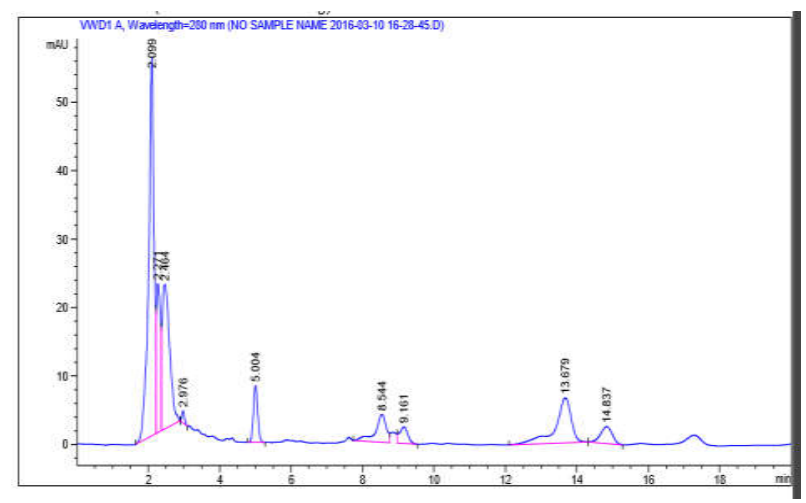

Figure III HPLC Profile of Coccinia grandis (leaf) at 280nmEstimation of polyphenols

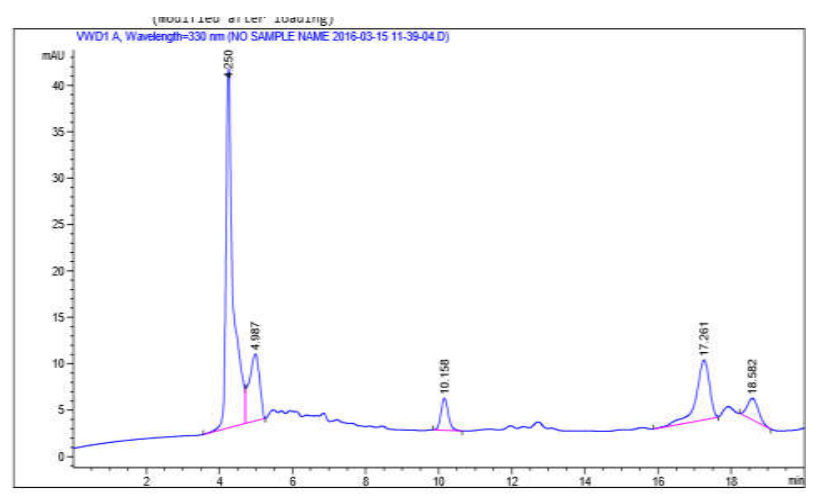

Figure IV HPLC Profile of Coccinia grandis (leaf) at 330nmEstimation of flavonoids

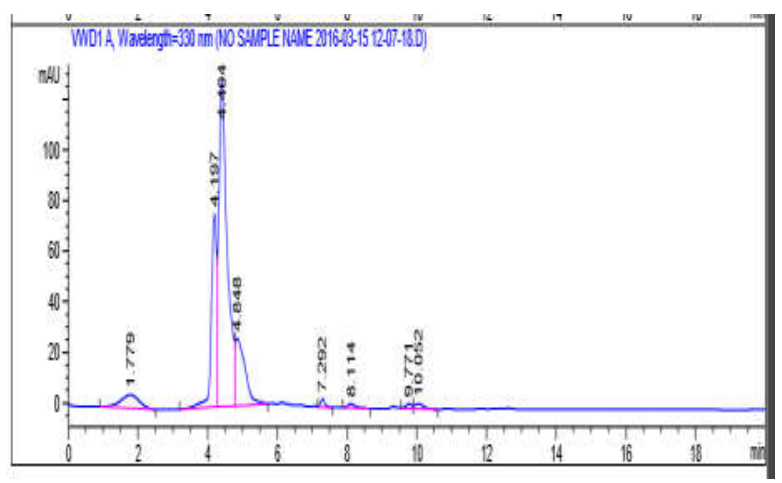

Figure V HPLC Profile of Coccinia grandis (fruit) at 330nmEstimation of flavonoids

The flavonoid content of the fruits was more compared to that of the contents in the leaf. The presence of flavonoids has been found to have antibacterial activity and researches are under progress to find the role of flavanoids in cancer (Koleva et al., 2002). 


\section{CONCLUSION}

The present study suggested that the selected plant, C.grandis could be a prospective resource of natural antioxidant owing to the presence of secondary metabolites like terpenoids, saponin and flavonoids, proteins and carbohydrates and thus could be used as therapeutic agent used as antioxidant, antidiuretic, anti-inflammatory, antianalgesic, anticancer agents. Further studies will be carried out in this plant in order to isolate, identify, characterize and elucidate the structure of the bioactive compounds.

\section{Acknowledgements}

We express our indebtedness and sense of gratitude to Chairman, Director, Chief executive and Principal of Bannari Amman Institute of Technology, Sathyamangalam for providing the necessary facilities

\section{References}

1. Ashish, S., Ujwala, R., Sugandha, G., Deshpande, S.V., Aniket, A. and Sandeep, G. 2011. Analgesic and antipyretic activity of methanolic extract of Coccinia grandis L. leaves in experimental animals. Research Journal of Pharmaceutical, Biological and Chemical Sciences., 2 (4):175-182.

2. Bamba, J.P., Miller, R.H. and Reddy, V.P. 2009. Studies on the biology, host specificity and feeding behavior of Acythopeuscocciniae O'Brien and Pakaluk (Coleoptera: Curculionidae) on Coccinia grandis (L.) Voigt (Cucurbitaceae) and Zehneriaguamensis (Merrill) Fosberg (Cucurbitaceae). Micronesica., 41(1):71-82.

3. Chandaka, M. and Ramanjaneyulu M. 2013. Evaluation phytochemical screening, analgesic and anti-inflammatory activity (synergic activity) of hydroalcoholic extract of Coccinia grandis. International Journal of Pharma and Bio Sciences., 4(4):180-186.

4. Chun, M.E. 2001. Biology and host specificity of Melittia oedipus (Lepidoptera: Sessidae), a biological control agent of Coccinia grandis (Cucurbitaceae). Proceedings of the Hawaiian Entomological Society., 35:41-45.

5. Deshpande, S.V., Patil, M.J., Parmar, K.K., Daswadkar, S.C. and Khodade. 2011. A study on antioxidant activity of fruit extracts of Coccinia grandis. International Journal of Drug Research and Technology., 1(1):69-72.

6. Eleazu, C.O., Eleazu, K.C., Awa, E. and Chukwuma, S.C. 2012. Comparative study of the phytochemical composition of the leaves of five Nigerian medicinal plants. Journal of Biotechnology and Pharmaceutical Research., 3(2):42-46.

7. Guidance for industry - Investigating out-ofspecification test results for pharmaceutical production. US Food and Drug Administration, Centre for Drug Evaluation and Research (CDER), October 2006.
8. Harborne, A.J. 1998. Phytochemical methods, A guide to modern techniques of plant analysis. Chapman ands Hall.

9. Hossain, S.K., Uddin, N., Abu, S. and Razaul, H. 2014. Phytochemical and Pharmacological screening of Coccinia grandis Linn. Journal of Scientific and Innovative Research., 3(1):65-71.

10. Hudzicki. J. 2009. Kirby-Bauer Disk Diffusion Susceptibility Test Protocol. American Society for Microbiology., 28:2039-2045.

11. Lowry, O.H., Rosebrough, N.J., Lewis, F. and Randall, R.J. 1951. Protein measurement with the folin phenol reagent. Journal for Biological Chemistry., 193(1): 265-75.

12. Muniappan, R., Reddy, V.P. and Raman, A. 2009. Coccinia grandis (L.) Voigt (Cucurbitaceae). Biological Control of Tropical Weeds used Arthropods. Cambridge University Press.

13. Nanasombat, S. and Teckchuen, N. 2009. Antimicrobial, Antioxidant and anticancer activities of Thai local vegetables. Journal of Medicinal Plants Research., 3(5): 443-449.

14. Pekamwar SS, Kalyankar TM, Kokate SS. 2013Pharmacological Activities of Coccinia grandis: Review. Journal of Applied Pharmaceutical Science., 3:114-119.

15. Quality assurance of pharmaceuticals. A compendium of guidelines and related materials. Vol. 2, 2nd updated edition. Good manufacturing practices and inspection. Geneva, World Health Organization, 2007.

16. Sanskriti, G., Anju, M. and Nidhi, S. 2014. A brief study on phytochemical compounds present in Coccinia cordifolia for their medicinal, pharmacological and industrial applications. World Journal of Pharmacy and Pharmaceutical Science., 3:1995-2016.

17. Syed, Z., Shaheen., Krishna, B., Kandukuri, V. and Singara, C. 2009. Antimicrobial activity of the fruit extracts of Coccinia indica. African Journal of Biotechnology., 8 (24):7073-7076.

18. Tamilselvan, N., Thirumalai, T., Elumalai, E.K., Balaji, R. and David, E. 2011. Pharmacognosy of Coccinia grandis: a review. Asian Pacific Journal of Tropical Biomedicine., 8:S299-S302.

19. Trease, G.E. and Evans, W.C. Pharmacognosy. 1989. Bailliere Tindall, London, Edn 11.

20. Uma, B. 2009, Cladistic analyses of a few members of Cucurbitaceae using rbcL nucleotide and amino acid sequences. International Journal of Bioinformatics Research., 1:58-64.

21. Umamaheswari, M., Chatterjee, T.K. 2009. Effect of the fractions of Coccinia grandis on Ethanol Induced cerebral oxidative stress in rats. Pharmacognosy Research., 1(1):25-34.

22. Umbreen, F., Huma, S., Shaukat, M., Syed, A.A. and Rizwani, H. 2008. Antibacterial activities of Coccinia grandis L.. Pakistan Journal of Botany., 40:12591262. 